\title{
PENGEMBANGAN MODEL ADOPSI TEKNOLOGI INFORMASI TERHADAP MODEL PENERIMAAN TEKNOLOGI DIANTARA UMKM
}

\author{
Asrul Sani1; Ninuk Wiliani²; Agus Budiyantara3 ${ }^{3}$; Nur Nawaningtyas ${ }^{4}$
}

Teknik Informatika

STMIK Widuri

www.kampuswiduri.ac.id

asrulsani@kampuswiduri.ac.id, agusbudiyantara@kampuswiduri.ac.id,tyaspusparini@kampuswiduri.ac.id,

Sistem Teknologi Informasi

Institut Teknologi dan Bisnis BRI

www.bri-institute.ac.id

ninukwiliani@bri-institute.ac.id

\begin{abstract}
This study is preliminary in the development of a new model whereby combining and integrating an existing model, the adoption model of information technology with the technology acceptance model. The development of this model is done by using the logic of the IPO (input-process-output) and the causal model by combining, adopting, and adapting the previous model. The effect of the formed path consists of 16 links and produces 11 variables. The existing variables will be formed into 55 indicators, where one variable creates five indicators. The process of developing this model will assist researchers in testing the information technology adoption model and the technology acceptance model so that it will get the effect that occurs in both models. This research will also contribute to further research, especially in the study of information systems, which will provide a theoretical basis for modeling. Besides, the transparency of the development and proposed models, especially in the instruments used, will be taken into consideration in conducting further research .
\end{abstract}

\section{Keywords: IT Adoption, TAM, Model Development}

Studi ini adalah studi awal dalam pengembangan model terbaru dimana dengan mengkombinasikan dan mengintegrasikan model yang sudah ada sebelumnya yaitu model adopsi teknologi informasi dengan model penerimaan teknologi. Pengembangan model ini dilakukan dengan menggunakan logika IPO (input-process-output) dan model sebab akibat dengan melakukan kombinasi, adopsi dan adaptasi pada model model sebelumnya. Pengaruh jalur path yang terbentuk terdiri dari 16 links dan menghasilkan 11 variabel. Pada variabel yang ada akan dibentuk menjadi 55 indikator, dimana 1 variabel membentuk 5 indikator. Proses pengembangan model ini akan membantu peneliti dalam melakukan pengujian pada model adopsi teknologi informasi dan model penerimaan teknologi sehingga akan mendapatkan pengaruh pengaruh yang terjadi pada kedua model tersebut. Penelitian ini juga akan memberikan konstribusi untuk penelitian selanjutnya, terutama dalam studi sistem informasi yang akan memberikan dasar teori dalam pemodelan. Selain itu, transparansi pengembangan dan model yang diusulkan terutama dalam instrumen yang digunakan, akan dijadikan poin pertimbangan dalam melakukan penelitian selanjutnya.

Kata Kunci: Adopsi TI, TAM, Pengembangan Model

\section{PENDAHULUAN}

Perkembangan Teknologi Informasi (TI) khususnya di Indonesia memberikan dampak positif terhadap peningkatan keberdayaan ekonomi secara nasional. Hal ini dibuktikan dengan semakin meningkatnya aktivitas kewirausahaan baik di sektor industri maupun disektor retail. Aktivitas kewirausahaan merupakan salah satu syarat untuk sebuah keberhasilan pembangunan, penciptaan lapangan kerja dan pencapaian stabilitas politik (Eggers, Kraus, Hughes, Laraway, \& Snycerski, 2013; Filser \& Eggers, 2014)

Dalam hal pengembangan kewirausahaan, Indonesia mempunyai peranan penting dalam meningkatkan kemajuan ekonomi, terutama dalam konteks Usaha Mikro, Kecil dan Menengah (UMKM). Indonesia yang merupakan negara berkembang sangat membutuhkan keberadaan UMKM terutama peran masyarakat dalam peningkatan ekonomi, peningkatan produktivitas, efesiensi, peningkatan distribusi pendapatan dan penjualan sehingga menjadikan pondasi ekonomi selama ada kemerosotas perekonomian (Abdullah, Manan, \& Khadijah, 2011).

Krisis ekonomi yang menimpa Indonesia di tahun 1997 - 1998 merupakan pelajaran berharga 
yang harus dijadikan dasar dimana UMKM adalah kegiatan usaha yang mampu berdiri kokoh tanpa ada kendala pada saat tersebut. Data Badan Pusat Statistik (BPS) menunjukkan pasca krisis ekonomi menujukkan adanya peningkatan tenaga kerja hingga 116,67 juta pada tahun 2017 . Kementerian Koperasi merilis data pertumbuhan UMKM diantara tahun 2012 - 2017 sebesar 13,98\% dengan peningkatan tenaga kerja sebesar 14,7\% (Koperasi, 2018). Faktor lain seperti tingkat pengetahuan dan pendidikan para pekerja dan pemilik UMKM, keterampilan dan tingkat kewirausahaan, akses UMKM kepada sumber pembiayaan, akses kepada lembaga pengembangan usaha, faktor faktor eksternal seperti kemudahan perijinan dan biaya transaksi dapat juga menggambarkan daya saing UMKM. Meskipun ukuran daya saing UMKM sangat beragam, identifikasi mengenai daya saing UMKM mencakup tiga karakteristik yaitu potensi, proses dan kinerja (Lantu, Triady, Utami, \& Ghazali, 2016)

Pengaruh postif dalam pemanfaatan teknologi informasi khususnya UMKM akan lebih meningkatkan kinerja di berbagai divisi seperti: pemasaran, komunikasi, produksi serta sumberdaya, sehingga dapat meningkatkan menajemen keuangan dan semua pemanfaatannya akan dapat melihat secara komprehensif perusahaan dengan baik (Chairoel, Widyarto, \& Pujani, 2015). Dari hasil penelitian ini akan ada 2 pertanyaan yang akan diberikan untuk memandu dan mengeksplorasi pelaksanaan penelitian yaitu:

Q1: Bagaimana memahami hubungan antara adopsi teknologi informasi terhadap penerimaan teknologi dikalangan UMKM?

Q2: Bagaimana mengembangkan adopsi teknologi informasi terhadap penerimaan teknologi dalam hal penggunaan teknologi informasi dikalangan UMKM?

Penelitian ini akan dibagi menjadi 4 bagian dimana bagian pertama akan menjelaskan latar belakang penelitian, kemudian diikuti penjelasan bahan dan metode dijanjutkan dengan hasil serta pembahasan dan diakhiri dengan kesimpulan dari penelitian

\section{BAHAN DAN METODE}

Studi pengembangan model ini dilakukan dengan mempersiapkan 5 (lima) tahapan (Gambar.1), yang dimulai dari studi literatur (1.1) dengan mempersiapkan model yang akan dikombinasikan yaitu model adopsi teknologi informasi dan model penerimaan teknologi. Model ini akan melihat jenis organisasi dan aspek sosial dari studi sistem informasi yang ada seperti kegunaan, kepuasan dan kesiapan (Nugroho, 2015; Sani, Subiyakto, \& Rahman, 2018)

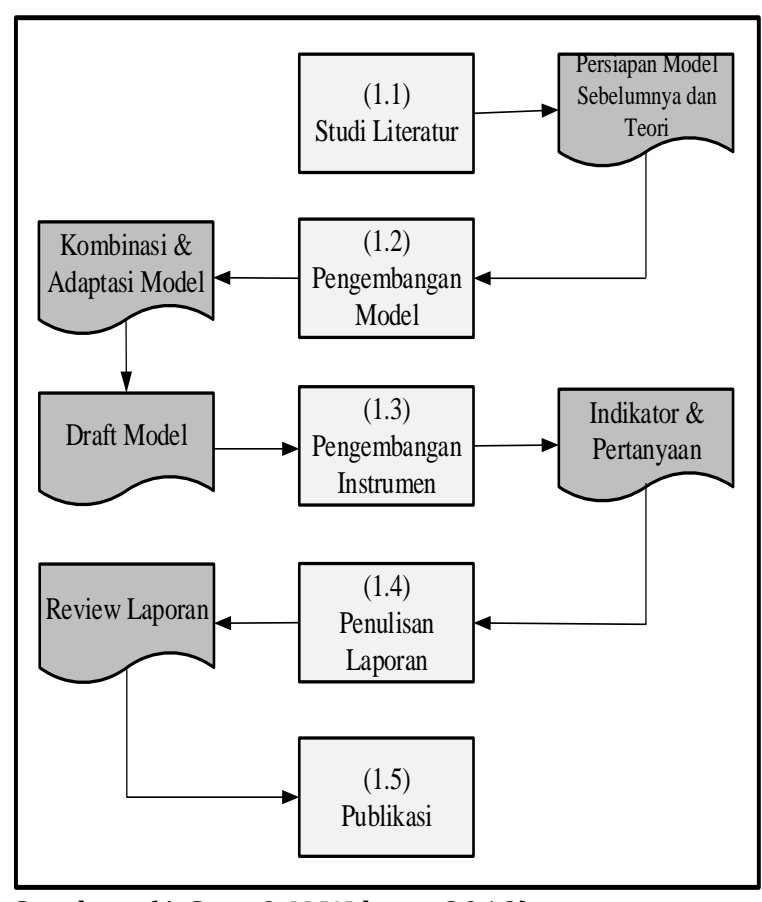

Sumber: (A Sani \& N Wiliani, 2019)

Gambar 1. Metode Penelitian

Tahap 1.2 adalah pengembangan model dengan melakukan literature review terhadap model, untuk menghasilkan model yang diinginkan sehingga terbentuk draft model. Terakhir, penelitian yang dikembangkan indikator dan instrumen (1.3) pengumpulan datanya kemudian diusulkan dalam tahap pelaporan (1.4), dalam hal penelitian penerapan yang nantinya akan dipublikasikan (1.5).

Tabel 1. Daftar model dan teori

\begin{tabular}{lc}
\hline \multicolumn{1}{c}{ Model dan Teori } & Referensi \\
\hline Teori Proses Informasi & (W. S. Davis \& Yen, \\
& 1998; Subiyakto \& \\
& Ahlan, 2014) \\
\hline Model Adopsi Teknologi & (Chatzoglou \& \\
& Chatzoudes, 2016; \\
& Sani et al., 2018; Zhu, \\
& Kraemer, \& Xu, 2003) \\
\hline Model Penerimaan & (F. D. Davis, 1989) \\
Teknologi & \\
\hline Model Proses dan Kausal & (Eddy et al., 2012; \\
pada Model & Kellogg, 2004; Petter, \\
Pengembangan & DeLone, \& McLean, \\
& 2008)(Sani, Rahman, \\
& Subiyakto, \& Wiliani, \\
& 2019)
\end{tabular}

Sumber: (Sani et al., 2018; A Sani \& N Wiliani, 2019) 


\section{HASIL DAN PEMBAHASAN}

Pada gambar 2 ditampilkan rancangan model pengembangan, yang merupakan penelitian pengembangan model sebelumnya, dimana sebagian besar model penelitian Sistem Informasi adalah cenderung dikembangkan secara praktis menggunakan model model sebelumnya dari pada berdasarkan studi empiris (Anfara Jr \& Mertz, 2014; Sani et al., 2019; Subiyakto \& Ahlan, 2014).

Secara umum, rancangan model dikembangankan dengan mengadopsi, menggabungkan dan adaptasi model adopsi TI (Chatzoglou \& Chatzoudes, 2016; Zhu et al., 2003) dengan model penerimaan teknologi (F. D. Davis, 1989). Model adopsi TI mempunya 6 variabel yaitu, Technology Competence (TEC), Firm Scope (FSC), Firm Size (FSZ), Consumer Readiness (CRD), Competitive Pressure (CPR), dan Lack of trading partner readiness (TPR). Model penerimaan teknologi terdiri dari 4 variabel yang terdiri dari Perceived Usefulness (PU), Perceived Ease of Use (PEU), Attitude Toward Using (ATU), dan Behavioral Intention to Use (BIU).

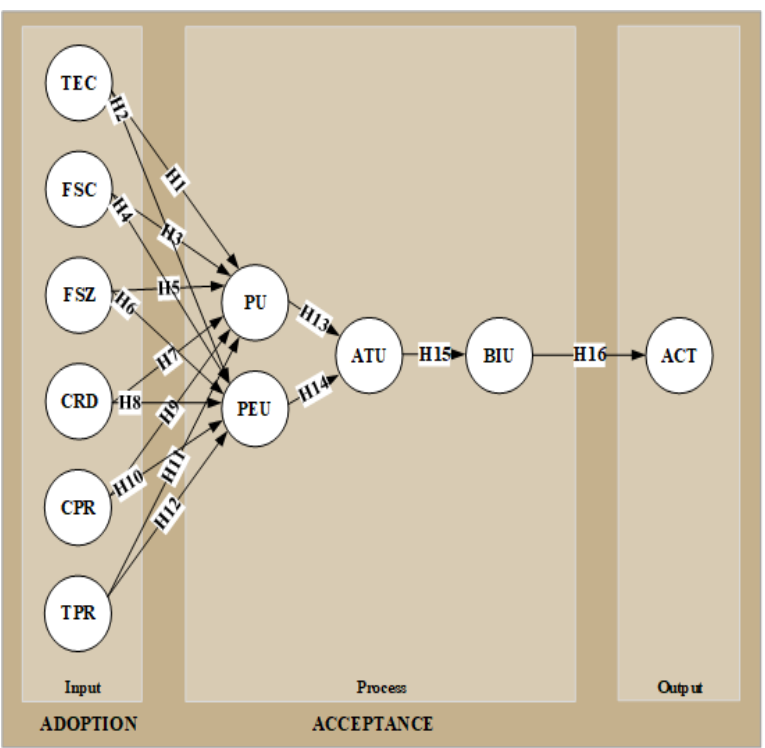

Sumber: (A Sani \& N Wiliani, 2019)

Gambar 2. Rancangan Model

Mengacu pada penelitian penelitian sebelumnya yang menggunakan logika Input Process - Output (IPO) (Sani et al., 2019; Sani et al., 2018; Asrul Sani \& Ninuk Wiliani, 2019) dalam pengembangan penelitian, peneliti berasumsi bahwa proses pengembangan model sistem informasi juga dapat diasumsikan dalam logika yang disebutkan pada logika IPO. Pada konteks dimensi model dari model pengembangan sistem informasi (DeLone \& McLean, 2003) dalam dimensi proses dan output logika IPO. Secara rinci, dimensi pembuatan sistem dan penggunaan sistem diasumsikan dalam satu proses, yang dalam hal ini adalah product life cycle (Jugdev \& Müller, 2005).

Tabel 2.Daftar variabel

\begin{tabular}{|c|c|c|}
\hline Kode & Nama & Definisi \\
\hline \multirow[t]{2}{*}{ TEC } & Technology & kepercayaan \\
\hline & Competence & $\begin{array}{l}\text { terhadap teknologi yang } \\
\text { memungkinkan organisasi } \\
\text { mengembangkan proses }\end{array}$ \\
\hline FSC & Firm Scope & $\begin{array}{lr}\text { Tingkat } & \text { kepercayaan } \\
\text { organisasi } & \text { dalam } \\
\text { mengembangkan } & \text { area } \\
\text { operasi perusahaan } & \\
\end{array}$ \\
\hline FSZ & Firm Size & $\begin{array}{ll}\text { Tingkat } & \text { kepercayaan yang } \\
\text { lebih } & \text { besar terhadap }\end{array}$ \\
\hline & & $\begin{array}{lrr}\text { organisasi } & \text { yang dapat } \\
\text { memiliki } & \text { keunggulan } \\
\text { kompetitif } & & \\
\end{array}$ \\
\hline CRD & Customer & Tingkat kepercayaan dari \\
\hline & Readiness & $\begin{array}{l}\text { konsumen terhadap } \\
\text { kemudahan internet }\end{array}$ \\
\hline CPR & $\begin{array}{l}\text { Competitive } \\
\text { Pressure }\end{array}$ & $\begin{array}{l}\text { Tingkat kepercayaan untuk } \\
\text { pengaruh industri, sehingga } \\
\text { terdapat cara untuk } \\
\text { mengungguli saingan. }\end{array}$ \\
\hline TPR & $\begin{array}{l}\text { Lack of } \\
\text { Trading } \\
\text { Partner } \\
\text { Readiness }\end{array}$ & $\begin{array}{lr}\text { Tingkat kepercayaan } \\
\text { terhadap status perdagangan, } \\
\text { dimana semua mitra dagang } \\
\text { harus mengadopsi } & \text { yang } \\
\text { kompatibel } & \text { sistem } \\
\text { perdagangan } & \text { secara } \\
\text { eloktronik. } & \\
\end{array}$ \\
\hline $\mathrm{PU}$ & $\begin{array}{l}\text { Perceived } \\
\text { Usefulness }\end{array}$ & $\begin{array}{l}\text { Tingkat kepercayaan dimana } \\
\text { penggunaan sistem akan } \\
\text { prestasi kerja seseorang }\end{array}$ \\
\hline PEU & $\begin{array}{l}\text { Perceive Ease } \\
\text { of Use }\end{array}$ & $\begin{array}{l}\text { Tingkat kepercayaan } \\
\text { terhadap TI yang akan } \\
\text { diaplikasikan adalah hal yang } \\
\text { membantu pekerjaan }\end{array}$ \\
\hline ATU & $\begin{array}{c}\text { Attitude } \\
\text { Toward Using }\end{array}$ & $\begin{array}{l}\text { Tingkat kepercayaan } \\
\text { terhadap evaluasi dari } \\
\text { pemakai tentang } \\
\text { keingintahuannya dalam } \\
\text { menggunakan teknologi }\end{array}$ \\
\hline BIU & $\begin{array}{l}\text { Behavioral } \\
\text { Intention to } \\
\text { Use }\end{array}$ & $\begin{array}{l}\text { Tingkat kepercayaan akan } \\
\text { kecenderungan perilaku } \\
\text { untuk tetap mengaplikasikan } \\
\text { sebuah teknologi }\end{array}$ \\
\hline ACT & $\begin{array}{l}\text { Actual } \\
\text { Acceptance } \\
\text { System }\end{array}$ & $\begin{array}{l}\text { Tingkat kepercayaan } \\
\text { terhadap penerimaan sistem } \\
\text { yang digunakan }\end{array}$ \\
\hline
\end{tabular}

Sumber: (Chatzoglou \& Chatzoudes, 2016; Sani et al., 2018; A Sani \& N Wiliani, 2019; Zhu et al., 2003)

Tabel 3. Daftar indikator

\begin{tabular}{ccl}
\hline Kode & \multicolumn{1}{c}{ Nama } & \multicolumn{1}{c}{ Definisi } \\
\hline TEC1 & Technologies & Tingkat terkait hardware \\
& & dan software dalam \\
& melakukan proses kerja \\
& & sehingga mudah \\
& & diimplemetasika \\
\hline TEC2 & Internet & Tingkat terkait pekerjaan \\
& & dengan konteks penggunan \\
\hline
\end{tabular}


VOL. 5. NO. 2 FEBRUARI 2020

P-ISSN: 2685-8223 | E-ISSN: 2527-4864

\begin{tabular}{|c|c|c|c|c|c|}
\hline Kode & Nama & Definisi & Kode & Nama & Definisi \\
\hline & & teknologi & & & dalam melakukan aktivitas \\
\hline TEC3 & Intranet & $\begin{array}{l}\text { Tingkat terkait antar } \\
\text { penggunan dalam } \\
\text { lingkungan tertentu }\end{array}$ & CPR2 & Pressure & $\begin{array}{l}\text { Tingkat terkait upaya untuk } \\
\text { membujuk dengan kekuatan } \\
\text { pendekatan seseorang }\end{array}$ \\
\hline TEC4 & E-mail & $\begin{array}{l}\text { Tingkat terkait } \\
\text { korespondensi sehingga } \\
\text { mudah dijangkau }\end{array}$ & CPR3 & Structure & $\begin{array}{l}\text { Tingkat terkait terhadap } \\
\text { kekuatan perusahaan dalam } \\
\text { berurusan dengan waktu }\end{array}$ \\
\hline \multirow[t]{2}{*}{ TEC5 } & \multirow[t]{2}{*}{ Tools } & \multirow{2}{*}{$\begin{array}{l}\text { Tingkat terkait penggunaan } \\
\text { perangkat sehingga mudah } \\
\text { tersambung satu sama } \\
\text { lainnya }\end{array}$} & CPR4 & Analysis & $\begin{array}{l}\text { Tingkat terkait terhadap } \\
\text { pemeriksaan sesuatu secara } \\
\text { rinci untuk dapat dijelaskan }\end{array}$ \\
\hline & & & \multirow[t]{2}{*}{ CPR5 } & \multirow[t]{2}{*}{ Integration } & \multirow{2}{*}{$\begin{array}{l}\text { Tingkat terkait terhadap } \\
\text { proses didalamnya dengan } \\
\text { kegiatan sepenuhnya }\end{array}$} \\
\hline \multirow[t]{2}{*}{ FSC1 } & \multirow[t]{2}{*}{ Reaches } & \multirow{2}{*}{$\begin{array}{l}\text { Tingkat terkait terhadap } \\
\text { jangkauan bisnis yang } \\
\text { mudah dijangkau untuk } \\
\text { pemasaran }\end{array}$} & & & \\
\hline & & & TPR1 & Beyond & $\begin{array}{l}\text { Tingkat terkait dimana } \\
\text { sebuah perusahaan harus }\end{array}$ \\
\hline \multirow[t]{2}{*}{ FSC2 } & \multirow[t]{2}{*}{ Variation } & \multirow{2}{*}{$\begin{array}{l}\text { Tingkat terkait terhadap } \\
\text { jenis pekerjaan yg dapat } \\
\text { dilakukan sesuai dengan } \\
\text { kapasitas }\end{array}$} & & & $\begin{array}{l}\text { memiliki pandangan jauh } \\
\text { kedepan untuk } \\
\text { pertumbuhan bersama }\end{array}$ \\
\hline & & & TPR2 & Supply Chain & Tingkat terkait terhadap \\
\hline \multirow[t]{2}{*}{ FSC3 } & \multirow[t]{2}{*}{ Establisment } & \multirow{2}{*}{$\begin{array}{l}\text { Tingkat terkait terhadap } \\
\text { kekuatan dan kelemahan } \\
\text { perkembangan perusahaan }\end{array}$} & & & $\begin{array}{l}\text { proses yang terlibat dalam } \\
\text { rantai pasokan produk }\end{array}$ \\
\hline & & & TPR3 & Compatible & Tingkat terkait terhadap ide \\
\hline \multirow[t]{2}{*}{ FSC4 } & \multirow[t]{2}{*}{ Operational } & \multirow{2}{*}{$\begin{array}{l}\text { Tingkat terkait terhadap } \\
\text { aktivitas berkelanjutan } \\
\text { produksi }\end{array}$} & & & $\begin{array}{l}\text { atau sistem yang kompatibel } \\
\text { bisa di jalankan bersama }\end{array}$ \\
\hline & & & TPR4 & Business & Tingkat terkait terhadap \\
\hline FSC5 & Geographic's & $\begin{array}{l}\text { Tingkat terkait terhadap } \\
\text { suasana keadaan pekerjaan } \\
\text { pada proses kegiatan }\end{array}$ & & Partner & $\begin{array}{l}\text { hubungan pengembangan } \\
\text { organisasi secara bersama } \\
\text { sama }\end{array}$ \\
\hline \multirow[t]{2}{*}{ FSZ1 } & \multirow[t]{2}{*}{ Data } & \multirow{2}{*}{$\begin{array}{l}\text { Tingkat terkait dalam } \\
\text { melihat jumlah data yang } \\
\text { digunakan berdasarkan } \\
\text { ukuran perusahaan }\end{array}$} & TPR5 & Significant & $\begin{array}{l}\text { Tingkat terkait terhadap } \\
\text { hubungan didalam } \\
\text { perusahaan }\end{array}$ \\
\hline & & & PU1 & Effectiveness & Tingkat terkait terhadap \\
\hline \multirow[t]{2}{*}{ FSZ2 } & \multirow[t]{2}{*}{ Clustering } & \multirow{2}{*}{$\begin{array}{l}\text { Tingkat terkait terhadap } \\
\text { sekelompok kecil orang atau } \\
\text { hal hal yang sangat dekat } \\
\text { satu sama lain }\end{array}$} & & & $\begin{array}{l}\text { ketepatan seseorang } \\
\text { menggunakan TI }\end{array}$ \\
\hline & & & PU2 & Performance & $\begin{array}{l}\text { Tingkat terkait kemampuan } \\
\text { seseorang dalam }\end{array}$ \\
\hline \multirow[t]{2}{*}{ FSZ3 } & \multirow[t]{2}{*}{ Employess } & \multirow{2}{*}{$\begin{array}{l}\text { Tingkat terkait terhadap } \\
\text { sejumlah karyawan yang } \\
\text { digunakan }\end{array}$} & & & menggunakan aplikasi \\
\hline & & & PU3 & Quality & $\begin{array}{l}\text { Tingkat terkait yang } \\
\text { berhubungan dengan hasil }\end{array}$ \\
\hline \multirow[t]{2}{*}{ FSZ4 } & \multirow[t]{2}{*}{ Classified } & \multirow{2}{*}{$\begin{array}{l}\text { Tingkat terkait terhadap } \\
\text { kategori jenis industri yang } \\
\text { diproduksi dengan melihat } \\
\text { besarnya aktivitas }\end{array}$} & & & $\begin{array}{l}\text { kerja dengan menggunakan } \\
\text { TI }\end{array}$ \\
\hline & & & PU4 & Productivity & $\begin{array}{l}\text { Tingkat terkait kecepatan } \\
\text { seseorang dalam bekerja }\end{array}$ \\
\hline \multirow[t]{2}{*}{ FSZ5 } & Model & Tingkat terkait terhadap & & & menggunakan TI \\
\hline & & $\begin{array}{l}\text { model yangdigunakan dalam } \\
\text { perusahaan disesuaikan } \\
\text { dengan jumlah karyawan }\end{array}$ & PU5 & Accomplish & $\begin{array}{l}\text { Tingkat terkait kemampuan } \\
\text { dalam menyelesaikan } \\
\text { persoalan dengan analisis }\end{array}$ \\
\hline CRD1 & Strategic & $\begin{array}{l}\text { Tingkat terkait terhadap } \\
\text { sesuatu yang direncanakan } \\
\text { untuk mendapatkan hasil } \\
\text { vano diinoinkan }\end{array}$ & PEU1 & Controllable & $\begin{array}{l}\text { Tingkat terkait dengan } \\
\text { adanya sistem yang mampu } \\
\text { mematau hasil pekerjaan }\end{array}$ \\
\hline CRD2 & Consumer & $\begin{array}{l}\text { yang diinginkan } \\
\text { Tingkat terkait dalam hal } \\
\text { seseorang yang melakukan } \\
\text { pembelian barang dan jasa }\end{array}$ & PEU2 & Cumbersome & $\begin{array}{l}\text { Tingkat terkait dengan } \\
\text { hubungan pemakaian TI } \\
\text { yang tidak sesuai dengan } \\
\text { kapasitas kerja yang }\end{array}$ \\
\hline CRD3 & Penetration & $\begin{array}{l}\text { Tingkat terkait perusahaan } \\
\text { dalam memasuki dunia TI }\end{array}$ & PEU3 & Frustrating & $\begin{array}{l}\text { dikerjakan } \\
\text { Tingkat terkait emosi }\end{array}$ \\
\hline CRD4 & Industry & $\begin{array}{l}\text { Tingkat terkait orang dan } \\
\text { organisasi yang terlibat } \\
\text { dalam produksi barang }\end{array}$ & & & $\begin{array}{l}\text { pengguna apabila ada TI } \\
\text { yang tidak dapat di } \\
\text { implemetasikan }\end{array}$ \\
\hline CRD5 & Driver & $\begin{array}{l}\text { Tingkat terkait terhadap } \\
\text { sesuatu yang membuat hal } \\
\text { hal penting terjadi }\end{array}$ & PEU4 & Understandable & $\begin{array}{l}\text { Tingkat terkait dengan } \\
\text { kemudahan dalam } \\
\text { menggunakan TI pada }\end{array}$ \\
\hline CPR1 & Competitive & Tingkat terkait perusahaan & & & pengaplikasian di \\
\hline
\end{tabular}




\begin{tabular}{|c|c|c|}
\hline Kode & Nama & Definisi \\
\hline & & perusahaan \\
\hline PEU5 & Mental Effort & $\begin{array}{l}\text { Tingkat terkait dimana } \\
\text { seseorang yang berusaha } \\
\text { untuk memahami TI dengan } \\
\text { berusaha untuk belajar }\end{array}$ \\
\hline ATU1 & Attitude & $\begin{array}{l}\text { Tingkat terkait seseorang } \\
\text { menggunakan aplikasi }\end{array}$ \\
\hline ATU2 & Evaluation & $\begin{array}{l}\text { Tingkat terkait terhadap } \\
\text { evaluasi dari pengguna } \\
\text { tentang keingintahuannya } \\
\text { menggunakan teknologi }\end{array}$ \\
\hline ATU3 & Users & $\begin{array}{l}\text { Tingkat terkait terhadap } \\
\text { pengguna dalam } \\
\text { menggunakan teknologi }\end{array}$ \\
\hline ATU4 & Curiosity & $\begin{array}{l}\text { Tingkat terkait pengguna } \\
\text { yang memiliki rasa } \\
\text { keingintahuannya terhadap } \\
\text { penggunaan teknologi }\end{array}$ \\
\hline ATU5 & Prediction & $\begin{array}{l}\text { Tingkat terkait terhadap } \\
\text { prediksi tingkah laku } \\
\text { pengguna dalam } \\
\text { penggunaan teknologi }\end{array}$ \\
\hline BIU1 & Behaviour & $\begin{array}{l}\text { Tingkat terkait terhadap } \\
\text { perilaku untuk tetap } \\
\text { mengaplikasikan sebuah } \\
\text { teknologi }\end{array}$ \\
\hline BIU2 & Influence & $\begin{array}{l}\text { Tingkat terkait terhadap } \\
\text { pengaruh yang diakibatkan } \\
\text { pengaplikasian sebuah } \\
\text { sistem }\end{array}$ \\
\hline BIU3 & Application & $\begin{array}{l}\text { Tingkat terkait terhadap } \\
\text { peningkatan produktivitas } \\
\text { dengan penggunaan } \\
\text { teknologi }\end{array}$ \\
\hline BIU4 & Gesture & $\begin{array}{l}\text { Tingkat terkait terhadap } \\
\text { kemampuan menggunakan } \\
\text { teknologi }\end{array}$ \\
\hline BIU5 & Attention & $\begin{array}{l}\text { Tingkat terkait terhadap } \\
\text { pentingnya perhatian untuk } \\
\text { penggunaan TI }\end{array}$ \\
\hline ACT1 & Acceptance & $\begin{array}{l}\text { Tingkat terkait terhadap } \\
\text { kemampuan penerimaan } \\
\text { pengguna terhadap } \\
\text { penggunaan TI }\end{array}$ \\
\hline ACT2 & Actual Use & $\begin{array}{l}\text { Tingkat terkait terhadap } \\
\text { seseorang yang terbukti } \\
\text { meningkatkan produktivitas } \\
\text { kerja. }\end{array}$ \\
\hline ACT3 & Usage & $\begin{array}{l}\text { Tingkat terkait dimana } \\
\text { pemakaian TI mampu } \\
\text { memberikan manfaat } \\
\text { produktivitas }\end{array}$ \\
\hline ACT4 & Measurement & $\begin{array}{l}\text { Tingkat terkait yang } \\
\text { berhubungan dengan } \\
\text { pengukuran hasil kerja } \\
\text { dengan penggunaan } \\
\text { teknologi }\end{array}$ \\
\hline ACT5 & Benchmark & $\begin{array}{l}\text { Tingkat terkait terhadap } \\
\text { pentingnya melihat } \\
\text { organisasi lain yang } \\
\text { menggunakan teknologi }\end{array}$ \\
\hline
\end{tabular}

Sumber: (Sani et al., 2018; A Sani \& N Wiliani, 2019)

Pada penelitian ini akan memberikan dua buah pemahaman utama yaitu berupa kepercayaan dan validitas masalah. Implementasi pada penelitian juga dilakukan secara terperinci dan jelas yang sudah dijelaskan pada bagian metode penelitian. Dalam hal ini dapat diperhatikan bagaimana penelitian menggunakan asumsi pengembangan model adopsi TI (Chatzoglou \& Chatzoudes, 2016; Zhu et al., 2003) dan adopsi penerimaan teknologi (F. D. Davis, 1989) dan menggabungkan kedua model tersebut, menyesuaikan dengan variabel, indikator serta pertanyaan yang akan membangun sistem pemanfaatan dari model terbaru ini.

Selain memanfaatkan kombinasi, asumsi serta proses adaptasi, pertanyaan yang akan diajukan pada kuesioner akan diambil secara terbalik berurutan berdasarkan pada banyaknya indikator, variabel dan asumsi yang ada, sehingga secara jelas nantinya akan memberikan pemahaman yang lebih detail dalam mengungkapkan karakteristik. Ungkapan karakteristik yang dimaksud adalah bagaimana menilai pengembangan adopsi TI di kalangan UMKM khususnya di Indonesia.

Tabel 4. Daftar pertanyaan dan pernyataan pada kuesioner

\begin{tabular}{cl}
\hline Kode & \multicolumn{1}{c}{ Pernyataan pada kuesioner } \\
\hline TEC1 & $\begin{array}{l}\text { Sistem dan teknologi mudah digunakan } \\
\text { dan diimplementasikan }\end{array}$ \\
\hline TEC2 & $\begin{array}{l}\text { Mudah menggunakan internet sebagai } \\
\text { fasilitas kerja }\end{array}$ \\
\hline TEC3 & $\begin{array}{l}\text { Sistem yang digunakan untuk penggunaan } \\
\text { aktivitas internal }\end{array}$ \\
\hline TEC4 & $\begin{array}{l}\text { Sistem yang digunakan sebagai fasilitas } \\
\text { korespondensi pekerjaan }\end{array}$ \\
\hline TEC5 & $\begin{array}{l}\text { Sistem yang digunakan sebagai fasilitas } \\
\text { terpadu satu sama lain }\end{array}$ \\
\hline FSC1 & $\begin{array}{l}\text { Sistem dapat membantu dan dapat } \\
\text { diandalkan untuk mendukung pemasaran }\end{array}$ \\
\hline FSC2 & $\begin{array}{l}\text { Sistem mampu untuk memaksimalkan } \\
\text { pekerjaan dengan baik sesuai kapasitas }\end{array}$ \\
\hline FSC3 & $\begin{array}{l}\text { Sistem tidak mudah terjadi kesalahan jika } \\
\text { kapasitas meningkat }\end{array}$ \\
\hline FSC4 & $\begin{array}{l}\text { Sistem dapat dihubungkan ke semua unit } \\
\text { sehingga kegiatan dapat berjalan dengan } \\
\text { baik }\end{array}$ \\
\hline FSC5 & $\begin{array}{l}\text { Sistem akan tetap berjalan walaupun ada } \\
\text { perpindahan tenaga kerja }\end{array}$ \\
\hline FSZ1 & $\begin{array}{l}\text { Sistem mampu memaksimalkan data dan } \\
\text { dapat menfasilitasi adopsi TI }\end{array}$ \\
\hline SSZ2 & $\begin{array}{l}\text { Sistem dapat menghubungkan antar } \\
\text { kelompok ataupun bagian }\end{array}$ \\
\hline
\end{tabular}




\begin{tabular}{|c|c|}
\hline Kode & Pernyataan pada kuesioner \\
\hline FSZ3 & $\begin{array}{l}\text { Sistem yang mampu menanggung resiko } \\
\text { terhadap pekerjaan karyawan }\end{array}$ \\
\hline FSZ4 & $\begin{array}{l}\text { Sistem mampu mengkalsifikasikan } \\
\text { kategori berdasarkan besarnya aktivitas }\end{array}$ \\
\hline FSZ5 & $\begin{array}{l}\text { Sistem berkaitas } \begin{array}{c}\text { dengan } \\
\text { perusahaan yang }\end{array} \\
\text { jumlah karyawan }\end{array}$ \\
\hline CRD1 & $\begin{array}{l}\text { Sistem merupakaan perencanaan yang } \\
\text { tepat untuk menghasilkan sesuatu }\end{array}$ \\
\hline CRD2 & $\begin{array}{l}\text { Sistem dapat menghubungan konsumen } \\
\text { dengan teknologi yang ada }\end{array}$ \\
\hline CRD3 & $\begin{array}{l}\text { Sistem adalah sebuah kesiapan konsumen } \\
\text { terhadap penetrasi teknologi }\end{array}$ \\
\hline CRD4 & $\begin{array}{l}\text { Sistem mampu mengorganisir pekerja } \\
\text { yang terlibat dalam produksi barang }\end{array}$ \\
\hline CRD5 & $\begin{array}{l}\text { Sistem merupakan pengembangan } \\
\text { fasilitas untuk memudahkan pekerja } \\
\text { terhadap hal hal yang baru }\end{array}$ \\
\hline CPR1 & $\begin{array}{l}\text { Sistem mampu mengubah persaingan } \\
\text { aturan sehingga mereka lebih kompetitif }\end{array}$ \\
\hline CPR2 & $\begin{array}{l}\text { Sistem mampu memanfaatkan cara baru } \\
\text { persaingan yang kompetitif }\end{array}$ \\
\hline CPR3 & $\begin{array}{l}\text { Sistem mampu untuk mempengaruhi } \\
\text { struktur agar menjadi lebih efisien }\end{array}$ \\
\hline CPR4 & $\begin{array}{l}\text { Sistem mempu memeriksa sesuatu } \\
\text { dengan rinci untuk dapat dijelaskan }\end{array}$ \\
\hline CPR5 & $\begin{array}{l}\text { Sistem mampu melakukan integrasi dan } \\
\text { migrasi sistem dengan baik }\end{array}$ \\
\hline TPR1 & $\begin{array}{l}\text { Sistem mampu untuk melayani sampau } \\
\text { jauh kedepan dengan integrasi antar } \\
\text { sistem }\end{array}$ \\
\hline TPR2 & $\begin{array}{l}\text { Sistem membutuhkan integrasi yang lebih } \\
\text { tepat dengan pelanggan dan pemasok }\end{array}$ \\
\hline TPR3 & $\begin{array}{l}\text { Sistem mapun melakukan analisis data yg } \\
\text { benar sehingga keputusan yang diambil } \\
\text { juga benar }\end{array}$ \\
\hline TPR4 & $\begin{array}{l}\text { Sistem dapat menghubungan semua mitra } \\
\text { dagang dengan mengadopsi perdagangan } \\
\text { elektronik yang kompatibel dalam sistem }\end{array}$ \\
\hline TPR5 & $\begin{array}{l}\text { Sistem mampu untuk menghubungkan } \\
\text { perusahaan dengan perusahaan lainnya }\end{array}$ \\
\hline PU1 & $\begin{array}{l}\text { Sistem memberikan efektivitas akibat dari } \\
\text { penggunaan TI }\end{array}$ \\
\hline PU2 & $\begin{array}{l}\text { Sistem mampu membuat seseorang untuk } \\
\text { dapat menggunakan aplikasi }\end{array}$ \\
\hline PU3 & $\begin{array}{l}\text { Sistem menghubungan hasil kerja dengan } \\
\text { kemampuan penggunaan TI }\end{array}$ \\
\hline PU4 & $\begin{array}{l}\text { Sistem mampu memberikan produktivitas } \\
\text { terhadap pekerjaan dengan menggunakan } \\
\text { TI }\end{array}$ \\
\hline PU5 & $\begin{array}{l}\text { Sistem mampu menyelesaikan setipa } \\
\text { persoalan dengan analisis yang tepat }\end{array}$ \\
\hline PEU1 & $\begin{array}{l}\text { Sistem mampu untuk memantau hasil } \\
\text { pekerjaan seseorang }\end{array}$ \\
\hline PEU2 & $\begin{array}{l}\text { Sistem yang mampu mendeteksi } \\
\text { penggunaan TI yang tidak praktis }\end{array}$ \\
\hline
\end{tabular}

\begin{tabular}{ll}
\hline Kode & \multicolumn{3}{c}{ Pernyataan pada kuesioner } \\
\hline PEU3 & $\begin{array}{l}\text { Sistem mampu menghilangkan frustasi } \\
\text { apabila ada TI yang tidak bisa } \\
\text { diimplementasikan }\end{array}$ \\
\hline PEU4 & $\begin{array}{l}\text { Sistem memudahkan pengguna dalam } \\
\text { pengaplikasian TI }\end{array}$ \\
\hline PEU5 & $\begin{array}{l}\text { Sistem mampu untuk membuat seseorang } \\
\text { memahami TI dengan baik }\end{array}$ \\
\hline ATU1 & $\begin{array}{l}\text { Sistem memberikan kepastian sikap } \\
\text { terhadap seseorang menggunakan } \\
\text { aplikasi }\end{array}$ \\
\hline ATU2 & $\begin{array}{l}\text { Sistem mampu memberikan evaluasi } \\
\text { terhadap pengguna tentang keingintahuan } \\
\text { menggunakan TI }\end{array}$ \\
\hline ATU3 & $\begin{array}{l}\text { Sistem membuat pengguna merasa } \\
\text { mampu untuk menggunakan TI }\end{array}$ \\
\hline ATU4 & $\begin{array}{l}\text { Sistem membuat pengguna memiliki rasa } \\
\text { ingin tahu terhadap TI }\end{array}$ \\
\hline ATU5 & $\begin{array}{l}\text { Sistem mampu memprediksi tingkah laku } \\
\text { pengguna dalam penggunaan TI }\end{array}$ \\
\hline BIU1 & $\begin{array}{l}\text { Sistem membuat perilaku pengguna } \\
\text { menjadi lebih baik dengan menggunakan } \\
\text { TI }\end{array}$ \\
\hline BIU2 & $\begin{array}{l}\text { Sistem memberikan pengaruh terhadap } \\
\text { pengguna TI }\end{array}$ \\
\hline BIU3 & $\begin{array}{l}\text { Sistem dapat meningkatkan produktivitas } \\
\text { dengan penggunaan TI }\end{array}$ \\
\hline BIU4 & $\begin{array}{l}\text { Sistem dapat melihat gerak tubuh } \\
\text { pengguna dalam menggunakan TI }\end{array}$ \\
\hline BIU5 & $\begin{array}{l}\text { Sistem mampu memperhatikan betapa } \\
\text { pentingnya penggunaan TI }\end{array}$ \\
\hline ACT1 & $\begin{array}{l}\text { Sistem mampu menerima adopsi TI pada } \\
\text { perusahaan }\end{array}$ \\
\hline ACT2 & $\begin{array}{l}\text { Sistem mampu meningkatkan kinerja } \\
\text { perusahaan dengan menggunakan TI }\end{array}$ \\
\hline ACT3 & $\begin{array}{l}\text { Sistem mampu memberikan manfaat } \\
\text { perusahaan dengan penggunaan TI }\end{array}$ \\
\hline ACT4 & $\begin{array}{l}\text { Sistem mampu mengukur kinerja pekerja } \\
\text { dengan penggunaan TI }\end{array}$ \\
\hline WCT5 & $\begin{array}{l}\text { Sistem harus dijadikan tolak ukur untuk } \\
\text { melihat keberhasilan pengguna }\end{array}$ \\
\hline 2019; A Sani \& N Wiliani, 2019) \\
\hline
\end{tabular}

\section{KESIMPULAN}

Studi penelitian ini adalah mengembangkan, memahami sehingga akan membuat pemahaman baru tentang hubungan antara adopsi TI terhadap penerimaan teknologi khususnya untuk kalangan UMKM. Pengembangan ini dilakukan dengan cara mengintegrasikan dua model yang sebelumnya sudah dilakukan sehingga akan menyempurnakan kedua model tersebut. Usulan model ini adalah mengkombinasikan enam variabel model adopsi TI dengan empat variabel model penerimaan 
teknologi. Kejelasan hubungan secara koheren antara variabel, indikator juga di tunjukkan dalam penelitian ini. Asumsi asumsi yang digunakan merujuk pada penulisan sebelum yang dijadikan referensi dalam menentukan pertanyaan maupun pernyataan dalam kuesioner. Beberapa keterbatasan yang ditunjukkan dijadikan titik pertimbangan untuk penelitian kedepannya, dan model yang diusulkan beserta instrumennya akan dilanjutkan pada tahap pemeriksaan dan pengembangan indikator dengan melakukan uji validitas dan uji reliabilitas.

\section{REFERENSI}

Abdullah, M. A., Manan, A., \& Khadijah, S. (2011) Small and Medium Enterprises and Their Financing Patterns: Evidence from Malaysia. Journal of Economic Cooperation \& Development, 32(2).

Anfara Jr, V. A., \& Mertz, N. T. (2014). Theoretical frameworks in qualitative research: Sage publications.

Chairoel, L., Widyarto, S., \& Pujani, V. (2015). ICT adoption in affecting organizational performance among Indonesian SMEs. The International Technology Management Review, 5(2), 82-93.

Chatzoglou, P., \& Chatzoudes, D. (2016). Factors affecting e-business adoption in SMEs: an empirical research. Journal of Enterprise Information Management, 29(3), 327-358.

Davis, F. D. (1989). Perceived usefulness, perceived ease of use, and user acceptance of information technology. MIS quarterly, 319-340.

Davis, W. S., \& Yen, D. C. (1998). The Information System Consultant's Handbook: Systems Analysis and Design: CRC press.

DeLone, W. H., \& McLean, E. R. (2003). The DeLone and McLean model of information systems success: a ten-year update. Journal of management information systems, 19(4), 930.

Eddy, D. M., Hollingworth, W., Caro, J. J., Tsevat, J., McDonald, K. M., \& Wong, J. B. (2012). Model transparency and validation a report of the ISPOR-SMDM Modeling Good Research Practices Task Force-7. Medical Decision Making, 32(5), 733-743.

Eggers, F., Kraus, S., Hughes, M., Laraway, S., \& Snycerski, S. (2013). Implications of customer and entrepreneurial orientations for SME growth. Management Decision, 51(3), 524-546.

Filser, M., \& Eggers, F. (2014). Entrepreneurial orientation and firm performance: A comparative study of Austria, Liechtenstein and Switzerland. South African Journal of Business Management, 45(1), 55-65.

Jugdev, K., \& Müller, R. (2005). A retrospective look at our evolving understanding of project success. Project Management Journal, 36(4), 19-31.

Kellogg, W. (2004). Logic model development guide. Michigan: WK Kellogg Foundation.

Koperasi, K. (2018). http://www.depkop.go.id/uploads/tx rtgf iles/SANDINGAN DATA UMKM 20122017.pdf.

Lantu, D. C., Triady, M. S., Utami, A. F., \& Ghazali, A. (2016). Pengembangan model peningkatan daya saing UMKM di Indonesia: Validasi kuantitatif model. The Asian Journal of Technology Management, 15(1), 77.

Nugroho, M. A. (2015). Impact of government support and competitor pressure on the readiness of SMEs in Indonesia in adopting the information technology. Procedia Computer Science, 72, 102-111.

Petter, S., DeLone, W., \& McLean, E. (2008). Measuring information systems success: models, dimensions, measures, and interrelationships. European Journal of Information Systems, 17(3), 236-263.

Sani, A., Rahman, T. K. A., Subiyakto, A. a., \& Wiliani, N. (2019). Combining Statistical and Interpretative Analyses for Testing Readiness and IT Adoption Questionnaire. Paper presented at the SEWORD FRESSH \#1.

Sani, A., Subiyakto, A., \& Rahman, T. K. A. (2018). Integration of the Technology Readiness and Adoption Models for Assessing IT Use among SMEs in Indonesia.

Sani, A., \& Wiliani, N. (2019). FAKTOR KESIAPAN DAN ADOPSI TEKNOLOGI INFORMASI DALAM KONTEKS TEKNOLOGI SERTA LINGKUNGAN PADA UMKM DI JAKARTA. 
JITK Uurnal Ilmu Pengetahuan Dan Teknologi Komputer), 5(1), 49-56.

Sani, A., \& Wiliani, N. (2019). Laporan Akhir Penelitian Mandiri. Jakarta.

Subiyakto, A., \& Ahlan, A. R. (2014). Implementation of Input-Process-Output Model for Measuring Information System Project Success. TELKOMNIKA Indonesian Journal of Electrical Engineering, 12(7), 5603-5612.

doi:http://doi.org/10.11591/ijeecs.v12.i7. pp5603-5612

Zhu, K., Kraemer, K., \& Xu, S. (2003). Electronic business adoption by European firms: a cross-country assessment of the facilitators and inhibitors. European Journal of Information Systems, 12(4), 251268. 